\title{
O Censo 70, o Impacto da Aứomação e uma Breve Lembrança do Doutor Hollerith
}

JUAREZ BAHIA

Professor da Escola de Comunicações e Artes da USP

Além das perspectivas naturais que vai abrir, o Censo 70 despertará para todo o País a justa dimensão do exercicio de novos mecanismos pela administração pública, em têrmos de adaptação dos sistemas de decisão e contrôle às exigências nacionais. Um dêsses mecanismos, agora usado em larga escala e com fins qualitativos fundados em elementos científicos, é o conjunto de processamento de dados. Aos computadores ficou reservada uma tarefa comunicativa que se enquadra mais no plano da informática, com suas projeções cibernéticas, do que pròpriamente no plano da informação clássica, linear, inspirada na tipografia e simbolizada em velhos instrumentos, como por exemplo a máquina do Doutor Hollerith.

Velhos instrumentos simplesmente aposentados, é certo, mas não desmoralizados. Pois, històricamente, a informática procede das máquinas mecanográficas a cartões perfurados, cuja atividade substancial era mesmo a adição Q a subtração. O Doutor Hollerith deve figurar entre os pioneiros talvez involuntários da informática. Pois sua má- quina constitui uma etapa avançada no campo dos cálculos. E, afinal, que são os computadores senão um formidável sistema de máquinas calculadoras? Num primeiro aspecto, a informática é representativa da multiplicidade de dados e da programação operacional com base na computação, o que mais aproxima o Doutor Hollerith de nosso tempo, antes de o afastar.

Foi um recenseamento nos Estados Unidos que motivou, na década de 1890 , a necessidade da automação. 0 censo anterior, em 1880, apurado com lápis e papel, reclamaria dez anos de conferências e constatações, de relações e interpretações, afetando o trabalho a ser desenvolvido a partir de 1890. Contratou-se, então, Herman Hollerith, inventor do sistema de processamento automático de dados, o homem que deu seu nome ao chamado sistema de cartōes perfurados.

Hoje, as máquinas Hollerith parecem velharias para as quais a mais generosa referência é de associação com museus. Mas várias décadas passaram até que o primeiro sistema de cálculo 
eletrônico para processamento de dados, o Univac I, pudesse entrar em funcionamento. Foi para o registro dos censos de 1950 sôbre população, habitação e agricultura que os novos computadores eletrônicos trabalharam. De 1950 a 1970 pode-se falar francamente em impacto da automação na administração pública mundial e também raciocinar com a existência de mil sistemas de computadores eletrônicos mais modernos e mais completos que o Univac.

O Brasil é testemunha dêsse impacto. $\operatorname{Em} 70$, o complexo de recursos humanos e eletrônicos não deixa lugar para uma confissão como esta, de Rafael Xavier sôbre o Censo de 1960: "A verdade é uma só - dizia êle lamentável sob todos os aspectos: o Censo de 60 fracassou. Não acredito que seja possivel refazer os dados mal coligidos, a não ser os demográficos. Isso, entretanto, não implicará no levantamento das necessidades do País, tão indispensável ao nosso progresso. Além do fracasso interno, quebramos nossos compromissos com a Unesco e nos desmoralizamos no exterior". Vínhamos de uma experiência menos má com o Censo de 1950, mas, nem de longe chegariamos aos resultados do Censo de 1940, de todos o mais completo, com pesquisas sôbre a demografia, a agricultura, a indústria, o comércio, os transportes, as comunicações, os serviços e a estrutura social.

- Censo 70 retomará essa linha prospectiva do futuro ensaiada pelo Censo de 1940. E ampliará nosso conhecimento de nós mesmos, pois cuida de investigações mais agudas no tempo e no espaço e conta com subsidios materiais que em nenhuma época estiveram ao alcance dos recenseadores. No entanto, nem só os efeitos de um treinamento adequado e de um elenco de recursos técnicos devem fornecer o crédito de êxito para o Censo 70 . Quer dizer: só o fato de no lugar do Doutor Hollerith figurar o computador não é suficiente para atribuir à grande pesquisa um resultado satisfatório.

Há um dado histórico que não pode ser esquecido. É o de nossa vocação censitária. Oficialmente, ela começa em 1872 com o primeiro recenseamento realizado com a aplicação de princípios técnicos de apuração. A população brasileira, calculada em 1870 , era de 10.112.061 habitantes. Cem anos depois, estamos na previsão a ser confirmada de mais de 90 milhões. Porém, nossa vocação censitária é muito anterior a 1870 e 1872. Ela se pronuncia mais precisamente aí por volta de 1583, com José de Anchieta a efetuar a primeira estimativa demográfica: 25 mil brancos, 18 mil e 500 indios civilizados e 14 mil escravos africanos.

Numa pequena faixa colonizada pelos portuguêses acha-se o campo para a investigação e o cálculo do padre Anchieta. Não só poeta, nem só catequizador, nosso grande jesuíta; também estatístico. Daí por diante é possível acompanhar a evolução populacional brasileira: $1776,1.900 .000$ habitantes; 1808/1810, 4 milhões; 1815 , $2.860 .525 ; 1817$, 3.300.000; 1819, $4.396 .132 ; 1825$, 5 milhões; 1827 , $3.758 .000 ; 1829,2.617 .900 ; 1830$, $5.340 .000 ; 1850$, 8 milhões; 1856 , $7.677 .000 ; 1867,11.780 .000 ; 1869$, $10.415 .000 ; 1870,10.112 .061 ; 1890$, $14.333 .915 ; 1900,17.318 .556 ; 1920$, 
$30.635 .605 ; 1940,41.236 .315 ; 1950$; 51.944.397; 1960, 70.967.000.

Talvez, acima de tudo que é possível esperar-se neste primeiro ano da década 70 , o Censo, mais que qualquer outra iniciativa pública ou privada, na área administrativa ou em qualquer outra, possa oferecer uma precisa medida do impacto da automação no sistema governamental brasileiro. Tal medida poderá ser sentida por todos à proporção que o País vá tomando melhor sentido de si mesmo - para lembrar Sócrates, vá se conhecendo melhor a si próprio - e também à proporção que os efeitos dessa causa assumam o desejado lugar no processo do desenvolvimento.

Assim, em têrmos de impacto da automação no Govêrno Federal, o Censo e tôda a sua complexa instrumentalização de prognósticos e verificações não podem ficar como ilhas no contexto administrativo. Como impacto, sua conseqüência há de significar um desencadeamento de novos métodos, novas técnicas, novos hábitos e novos comportamentos, à altura das vantagens de um processamento eletrônico moderno e capaz de responder aos desafios de uma gigantesca tarefa burocrática. 


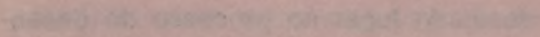

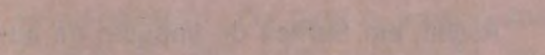

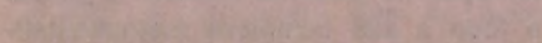
19.

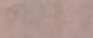

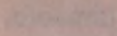

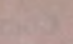

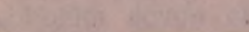

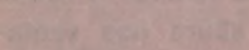

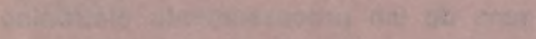

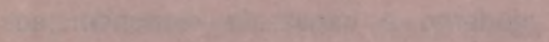

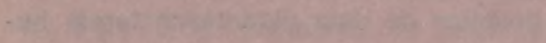

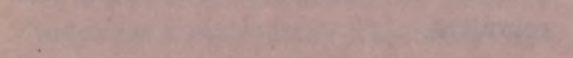

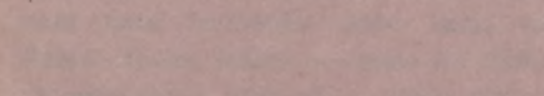

